\title{
Glyphosate applied at low doses can stimulate plant growth
}

Edivaldo D Velini, ${ }^{1 *}$ Elza Alves, ${ }^{2}$ Maria C Godoy, ${ }^{1}$ Dana K Meschede, ${ }^{1}$ Reginaldo T Souza ${ }^{3}$ and Stephen O Duke

${ }^{1}$ São Paulo State University, Faculty of Agronomic Sciences, Experimental Station Lageado, Laboratory of Weed Science, Botucatu, SP, Brasil CEP 18603-970 PB 237, Brazil

${ }^{2}$ São Paulo State University, Faculty of Agronomic Sciences, Registro, SP, Brazil

${ }^{3}$ EMBRAPA - Brazilian Agricultural Research Corporation, Embrapa Grape and Wine, Tropical Grapevine Experimental Station, Brazil

${ }^{4}$ PO Box 8048, Natural Products Utilization Research Unit, US Department of Agriculture, University, MS 38677, USA

\section{Abstract}

BACKGROUND: Glyphosate blocks the shikimic acid pathway, inhibiting the production of aromatic amino acids and several secondary compounds derived from these amino acids. Non-target plants can be exposed to low doses of glyphosate by herbicide drift of spray droplets and contact with treated weeds. Previous studies have reported that low doses of glyphosate stimulate growth, although these data are very limited. The objective of this study was to determine the effects of low glyphosate doses on growth of a range of plant species.

RESULTS: Growth of maize, conventional soybean, Eucalyptus grandis Hill ex Maiden, Pinus caribea L. and Commelia benghalensis $\mathrm{L}$. was enhanced by 1.8-36 glyphosate $\mathrm{ga}^{-1}$. Growth of glyphosate-resistant soybean was unaffected by any glyphosate dose from 1.8 to $720 \mathrm{~g} \mathrm{AE} \mathrm{ha}^{-1}$. The optimum doses for growth stimulation were distinct for plant species and tissue evaluated. The greatest stimulation of growth was observed for C. benghalensis and $P$. caribea. Shikimic acid levels in tissues of glyphosate-treated soybean and maize were measured and found to be elevated at growth-stimulating doses.

CONCLUSION: Subtoxic doses of glyphosate stimulate the growth of a range of plant species, as measured in several plant organs. This hormesis effect is likely to be related to the molecular target of glyphosate, since the effect was not seen in glyphosate-resistant plants, and shikimate levels were enhanced in plants with stimulated growth.

(C) 2008 Society of Chemical Industry

Keywords: Commelia benghalensis; Eucalyptus grandis; glyphosate; growth stimulus; hormesis; maize; Pinus caribea; soybean

\section{INTRODUCTION}

Glyphosate is the only commercially available herbicide that acts upon the enzyme 5-enolpyruvylshikimate-3-phosphate synthase (EPSPS), blocking the synthesis of aromatic amino acids and secondary compounds derived from these amino acids. ${ }^{1}$ Most plant species are sensitive to glyphosate, indicating little or no functional variability of EPSPS at the compound's binding site. EPSPS inhibition leads to accumulation of shikimate in plant tissues, ${ }^{1-4}$ a response that can be used as an indicator of plant sensitivity or exposure to this herbicide. ${ }^{5,6}$

Among environmental toxicologists there is concern over the effects of low doses of pesticides on nontarget organisms. ${ }^{7}$ Hormesis, the stimulatory effect of subtoxic doses of a toxicant, has been reported for low doses of many herbicides on plants, ${ }^{8,9}$ including glyphosate. ${ }^{8-11}$ In spite of glyphosate being the most widely used herbicide worldwide, limited information is available on the effects of low doses of this herbicide on plants.

The research reported in this paper is part of a project aimed at evaluating the effects of low doses of glyphosate on the growth of crop and weed species. Results obtained with Commelina benghalensis L., Eucalyptus grandis Hill ex Maiden, Pinus caribea L., maize and soybean demonstrating hormesis at low doses are presented in this paper.

\section{MATERIALS AND METHODS}

\subsection{General growth and treatment methods}

All of the experiments were carried out in greenhouses, keeping the air temperatures between 25 and $27^{\circ} \mathrm{C}$, with $70 \%$ relative humidity. Glyphosate was applied 
using microsyringes, leaving small droplets on the leaves, or was sprayed onto plants using a model 01 spray cabinet (MetalFortes, Botucato, SP, Brazil). The application volume of $200 \mathrm{~L} \mathrm{ha}^{-1}$ was achieved by using 8002 flat-fan nozzles at $3 \mathrm{~kg} \mathrm{~cm}^{-2}$ pressure and $1.25 \mathrm{~km} \mathrm{~h}^{-1}$ speed. A commercial glyphosateisopropylamine $480 \mathrm{~g} \mathrm{~L}^{-1}\left(360 \mathrm{~g} \mathrm{AE} \mathrm{L}^{-1}\right) \mathrm{SL}$ (Roundup Original ${ }^{\circledR}$, Monsanto Company) was used. The herbicide was applied at doses ranging from 0 to $2880 \mathrm{~g} \mathrm{AE} \mathrm{ha}^{-1}$ for the assay with $P$. caribea and from 0 to $720 \mathrm{~g} \mathrm{AE} \mathrm{ha}^{-1}$ for the other species. Water and nutrients were provided as required for normal growth and development of the plants. As glyphosate and phosphate possibly use similar transport proteins in plants, ${ }^{12,13}$ the phosphorus concentrations in the soil were adjusted to attain $100 \mathrm{mg} \mathrm{kg}^{-1}$ in all experiments. To measure the dry weights, only the living parts of plants that were not completely killed were considered.

\subsection{Plant materials}

\subsubsection{Maize and soybean}

Pregerminated seeds of maize (hybrid Santa Helena SHS 5060), conventional soybean (variety COODETEC CD 201) and glyphosate-resistant soybean (variety COODETEC CD 212RR) were transplanted to $3 \mathrm{~L}$ pots and kept under greenhouse conditions up to 14 days after emergence, when soybean and maize plants had 2-3 leaves and three leaves respectively. Glyphosate was sprayed at $0,1.8,3.6,7.2,18,36,72$, 180,360 and $720 \mathrm{~g} \mathrm{AE} \mathrm{ha}^{-1}$. Each dose was applied to four pots with two plants that were collected 21 days after treatment (DAT) to determine root and shoot dry weights.

\subsubsection{Commelina benghalensis}

Two preliminary field studies were carried out to estimate the individual dose received by individual plants with 2-4 leaves located between or within the soybean culture rows when the application was made with or without electrostatic charging of the droplets. Two types of spray equipment were used: Condor S-12 and Spra-Coupe 3640. The Spra-Coupe 3640 spray system applies droplets with or without electrostatic energy. In the first experiment (Botucatu, São Paulo State, Brazil), the sprayer S-12, equipped with nozzles $110-\mathrm{SF}-03$, applied $250 \mathrm{~L} \mathrm{ha} \mathrm{ha}^{-1}$ of a solution containing $0.18 \%$ of each one of the dyes FDC-1 and Saturn Yellow. As a target, 150 plants of $C$. benghalensis located between the rows were used. In the second experiment (Montividiu, Goias State, Brazil), the Spra-Coupe 3640 sprayer, equipped with nozzles TT11002, worked at 18 and $9 \mathrm{~km} \mathrm{~h}^{-1}$, applying 50 and $100 \mathrm{~L} \mathrm{ha}^{-1}$ of solutions containing $0.15 \%$ of FDC- 1 and $0.525 \%$ of Tartrasin Yellow respectively. After the applications, 150 plants of $C$. benghalensis were collected between or within the rows of soybean crops and washed in deionized water. The concentrations of the dyes in the water used to wash plants were measured by spectrophotometry, making it possible to calculate the spray deposits in $\mu \mathrm{Lplant}^{-1}$ or $\mu \mathrm{L} \mathrm{cm}^{-2}$ leaf area.

The doses used in the greenhouse experiment were selected to represent the unitary dosage variations observed in the field. Seeds obtained from AgroCosmos Seeds were used. The company harvests seeds in different regions, crops and production systems in Brazil and combines them to produce bulk seeds with high diversity.

In the first greenhouse experiment, glyphosate was applied to $C$. benghalensis at the two-leaf stage using one droplet of $2 \mu \mathrm{L}$ per leaf containing $0,0.0562$, $0.0659,0.0900,0.1019,0.1125,0.1404,0.1685$, $0.1872,0.225,0.45,0.9,1.8,2.7$ or $3.6 \mathrm{~g} \mathrm{AE} \mathrm{L}^{-1}$. Each dose was applied to ten plants, and at 14 DAT total dry weights were determined.

In a second greenhouse study, only plants at the four-leaf stage were used. Each plant received $20 \mu \mathrm{L}$ (one droplet of $5 \mu \mathrm{L}$ in each one of the four leaves) of $0.15,0.18,0.25,0.031,0.39,0.52,1.25,2.5$, $5.0,7.5,10.0,15.0$ or $20.0 \mathrm{~g} \mathrm{AE} \mathrm{L}^{-1}$. Each dose was applied to 28 plants. Total dry weights were determined 21 DAT.

\subsubsection{Eucalyptus grandis and Pinus caribea}

The E. grandis (hybrid Eucatex 105) and P. caribea var hondurensis (provenance Bofete, SP, Brazil, obtained from Eucatex Company) were transplanted to $10 \mathrm{~L}$ pots and kept under greenhouse conditions for 30 and 14 days prior to application respectively. Each rate was applied to eight plants. Eucalyptus grandis was sprayed with glyphosate at $0,1.8,3.6,7.2,18,36,72,180$, 360 or $720 \mathrm{~g} \mathrm{AE} \mathrm{ha}^{-1}$, and $P$. caribea was sprayed at $0,1.8,3.6,7.2,14.4,36,72,144,360,720,1440$ or $2880 \mathrm{~g} \mathrm{AE} \mathrm{ha}^{-1}$. Plants were collected $60 \mathrm{DAT}$ to measure leaf area and root, leaf, stem and total dry weights.

\subsection{Shikimic acid extraction and analysis}

The shikimic acid concentrations in the shoots of maize and soybean were evaluated by the procedure developed by Singh and Shaner, ${ }^{5}$ and the values are expressed in $\mu \mathrm{gg}^{-1}$ fresh weight. Plant material $(0.1 \mathrm{~g})$ was ground with liquid nitrogen and $3 \mathrm{~mL}$ of $0.25 \mathrm{M}$ hydrochloric acid. All shoot biomass of the two plants, including living and dead tissues, was used to make composite samples for each pot. The extracts were centrifuged at $25000 \times g$ for $15 \mathrm{~min}$. The supernatant $(100 \mu \mathrm{L})$ reacted with $1 \mathrm{~mL}$ of a $1 \%$ solution of periodic acid. After $3 \mathrm{~h}, 1 \mathrm{~mL}$ of $1 \mathrm{M}$ sodium hydroxide and $0.6 \mathrm{~mL}$ of $0.1 \mathrm{M}$ glycine were added to the samples. Absorbance was measured at $380 \mathrm{~nm}$.

\subsection{Statistical methods}

The models of Brain and Cousens ${ }^{14}$ and Streibig ${ }^{15}$ describing dose-response curves with or without hormesis were selected to be fitted to the data. The models are described as follows: 
Dose-response curve with hormesis

$$
y=F(x)=\frac{k+f x}{1+a x^{b}}+d
$$

Dose-response curve with hormesis

$$
y=F(x)=\frac{k+f x}{1+e^{b g} x^{b}}+d
$$

Dose-response curve without hormesis

$$
y=F(x)=\frac{k}{1+a e^{b \log x}}+d=\frac{k}{1+a x^{b}}+d
$$

Dose-response curve without hormesis

$$
y=F(x)=\frac{k}{1+e^{b g} x^{b}}+d
$$

where $e$ is the Neper number, $y$ represents the yield of the test plants, $x$ represents the herbicide dose, $K+d$ is the yield of the control, $d$ is the yield of dead plants and $a$ and $b$ determine the way in which yield decreases with dose.

Regarding equations (1a) and (2a), Brain and Cousens ${ }^{14}$ observe that, in the fitting procedure, $a$ and $b$ can be highly correlated, and they recommend the replacement of $a$ with $e^{b g}$, where $g=-\log _{\mathrm{e}}\left(\mathrm{ED}_{50}\right)$ and $\mathrm{ED}_{50}=a^{-1 / b}$ and is defined as the dose that gives $50 \%$ of the total achievable effect.

In this research, the models were used as represented in equations (1b) and (2b). These nested models differ in just one coefficient that multiplies the independent variable $x$, enabling calculation of the decrease in the residual sum of squares by including the coefficient $f$ with a value different from zero. The difference between the residual sums of the two models $\left(\mathrm{RS}_{\text {model 2 }}-\mathrm{RS}_{\text {model 1 }}\right)$ was tested for $P<0.05$ and at $P<0.01$ using the $F$ calculated as follows and where EEMS is the experimental error mean square:

$$
F=\frac{\mathrm{RS}_{\text {model 2 }}-\mathrm{RS}_{\text {model 1 }}}{\text { EEMS }}
$$

When the $F$ value was significant, the hypothesis that $f=0$ was rejected, the occurrence of a growth stimulus was accepted and the complete model [equation (1b)] was used. When the $F$ value was not significant, the hypothesis that $f=0$ was accepted, and so it was concluded that there was no stimulus at low doses, and a normal sigmoid model [equation (2b)] was fitted to the data. The use of this procedure is supported by Brain and Cousens ${ }^{14}$ and by Cedergreen et al., ${ }^{16}$ who point out that the Brain and Cousens ${ }^{14}$ model is not applicable when $f<0$ (the function has a valley instead of a peak) and if $b<1$ (the model does not yield any dose-response curve). These restrictions do not apply to the models fitted to the data in the present paper, as the values of $f$ and $b$ were all higher than 0 and 1 respectively.

\begin{tabular}{|c|c|c|c|}
\hline & \multicolumn{3}{|c|}{ Dry weight (\% of control) } \\
\hline & Root & Shoot & Total \\
\hline \multicolumn{4}{|c|}{ Glyphosate rate $(\mathrm{g} \mathrm{AE} \mathrm{ha-1)}$} \\
\hline 0 & 100.00 & 100.00 & 100.00 \\
\hline 1.8 & 108.14 & 107.83 & 107.90 \\
\hline 3.6 & 104.33 & 113.88 & 111.77 \\
\hline 7.2 & 101.55 & 118.10 & 114.46 \\
\hline 18 & 99.22 & 128.66 & 122.18 \\
\hline 36 & 88.63 & 101.15 & 98.39 \\
\hline 72 & 44.19 & 64.96 & 60.38 \\
\hline 180 & 39.79 & 41.67 & 41.26 \\
\hline 360 & 33.33 & 29.26 & 30.16 \\
\hline 720 & 27.13 & 23.64 & 24.41 \\
\hline $\begin{array}{l}\text { Coefficient of } \\
\text { variation (\%) }\end{array}$ & 22.73 & 13.42 & 10.43 \\
\hline \multicolumn{4}{|l|}{$F$-values: } \\
\hline $\begin{array}{l}\text { Treatments or } \\
\text { doses }\end{array}$ & $19.84^{* *}$ & $62.58^{* *}$ & $81.70^{* *}$ \\
\hline $\begin{array}{l}\text { Hypothesis } \\
\quad f \neq 0\end{array}$ & $0.11^{\mathrm{ns}}$ & $23.67^{* *}$ & $20.75^{* *}$ \\
\hline Regression & $286.05^{* *}$ & $667.54^{* *}$ & $290.50^{* *}$ \\
\hline Model & Equation (2b) & Equation (1b) & Equation (1b) \\
\hline$R^{2}$ & 0.9879 & 0.9978 & 0.9965 \\
\hline Constants & $\begin{array}{c}g=-3.8944 \\
b=4.1602 \\
K=69.840 \\
D=33.1232\end{array}$ & $\begin{array}{c}g=-3.3214 \\
b=2.0435 \\
k=78.047 \\
d=21.6532 \\
f=3.8878\end{array}$ & $\begin{array}{c}g=-3.4031 \\
b=2.1190 \\
k=76.933 \\
d=24.1002 \\
F=2.9153\end{array}$ \\
\hline
\end{tabular}

The statistical analysis was the same for all plant species, but the complete sets of results are presented
Table 1. Mean dry weights of conventional soybean plants treated at the 2-3-leaf stage and harvested 21 days after treatment

ns $=$ not significant; ${ }^{* *} P<0.01$

only for soybean and maize. For the other three species, only the best-fitting models are shown.

\section{RESULTS}

When applied within the range $72-720 \mathrm{~g} \mathrm{AE} \mathrm{ha}^{-1}$, glyphosate strongly inhibited conventional soybean growth (Table 1). Shoot and total dry weights were significantly elevated by low doses of glyphosate (1.8-18 $\left.\mathrm{g} \mathrm{AE} \mathrm{ha}^{-1}\right)$. The best-fitting models are in Fig. 1. Maximum shoot and total dry weights (128 and $122 \%$ of the control) were estimated for doses of 14.2 and $23 \mathrm{~g} \mathrm{ha}^{-1}$ respectively. For root dry weights, the hypothesis that $f=0$ was accepted, indicating that hormesis did not take place, and the logistic model, without stimulation at low doses, was fitted to the data. In contrast, the application of doses ranging from 1.8 to $720 \mathrm{~g} \mathrm{AE} \mathrm{ha}^{-1}$ did not affect the growth of glyphosate-resistant, transgenic soybean (Table 2).

The results observed for maize (Table 3, Fig. 1) are similar to those obtained for conventional soybean, but growth stimulation was observed in a wider range of doses (1.8-36 $\mathrm{g} \mathrm{AE} \mathrm{ha}^{-1}$ ). There was no effect of these low doses on the growth of roots. When applied at doses over $72 \mathrm{~g} \mathrm{AE} \mathrm{ha}^{-1}$, glyphosate inhibited maize growth. Except for root dry weights, the hypothesis 

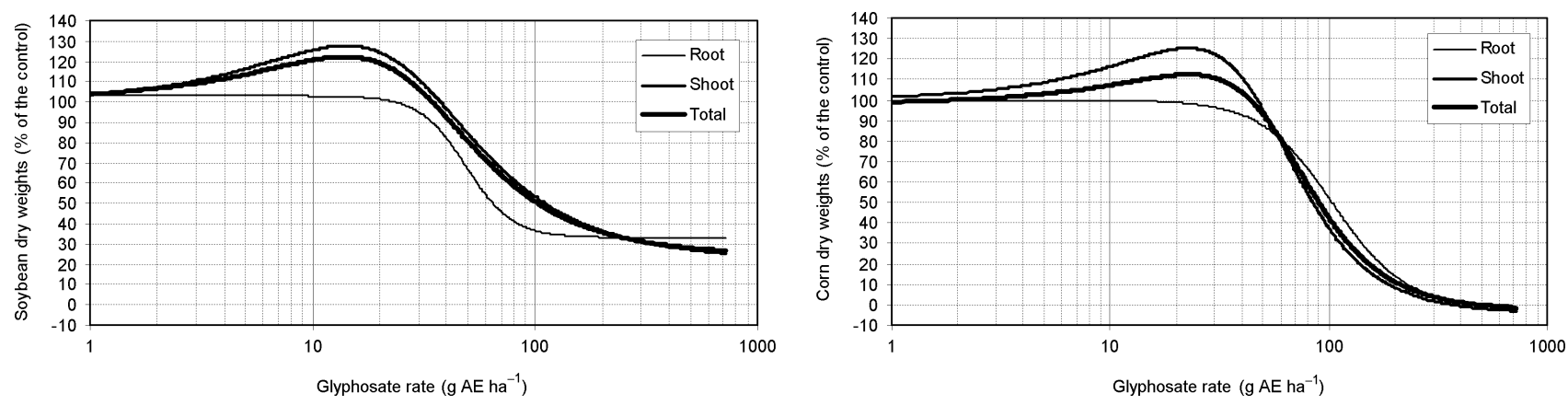

Figure 1. Curves representing conventional soybean sensitive to glyphosate (left) and maize (right) dry weights as a result of glyphosate application. Soybean plants were treated at the 2-3-leaf stage and maize plants at the three-leaf stage. Both species were harvested 21 days after glyphosate application.

Table 2. Mean dry weights of transgenic, glyphosate-resistant soybean plants treated at the 2-3-leaf stage and harvested 21 days after treatment

\begin{tabular}{lrrr}
\hline & \multicolumn{3}{c}{ Dry weight (\% of control) } \\
\cline { 2 - 4 } & Root & Shoot & Total \\
\hline Glyphosate rate (g AE ha-1) & & \\
0 & 100.00 & 100.00 & 100.00 \\
1.8 & 88.81 & 110.12 & 105.14 \\
3.6 & 113.58 & 106.33 & 108.02 \\
7.2 & 90.45 & 102.23 & 99.47 \\
18 & 105.53 & 118.71 & 115.63 \\
36 & 103.46 & 102.91 & 103.04 \\
72 & 87.88 & 94.76 & 93.15 \\
180 & 95.21 & 96.47 & 96.18 \\
360 & 99.87 & 107.98 & 106.09 \\
720 & 86.68 & 100.67 & 97.40 \\
\hline Coefficient of & 19.05 & 16.75 & 12.91 \\
variation (\%) & & & \\
\hline $\boldsymbol{F}$-values: & & & \\
Treatments or & $1.15^{\mathrm{ns}}$ & $0.82^{\mathrm{ns}}$ & $1.25 \mathrm{~ns}$ \\
doses & & & \\
\hline
\end{tabular}

$\mathrm{ns}=$ not significant.

that the constant $f$ is equal to zero was rejected and the model that predicts growth stimuli at low doses was fitted to the data. The best-fitting models are represented in Fig. 1. Maximum shoot and total dry weights ( 125 and $112 \%$ of the control) were estimated for doses of 22.6 and $23 \mathrm{~g} \mathrm{AE} \mathrm{ha}^{-1}$ respectively.

Glyphosate at low doses caused an increase in the concentration of shikimic acid in the shoots of conventional soybean and maize (Table 4), showing that glyphosate was inhibiting EPSPS in the plants. For the higher doses of glyphosate, most of the composite samples used to quantify shikimic acid corresponded to non-living tissues, indicating that shikimic acid was preserved, at least in part, in these dead tissues. In soybean, the concentrations of shikimate in tissues of plants subjected from the lowest to the highest dose did not vary much, whereas there was a more glyphosate dose-dependent relationship to shikimate content in maize tissues.
Table 3. Mean dry weights of maize plants treated at the three-leaf stage and harvested 21 days after treatment

\begin{tabular}{|c|c|c|c|}
\hline & \multicolumn{3}{|c|}{ Dry weight (\% of control) } \\
\hline & Root & Shoot & Total \\
\hline \multicolumn{4}{|c|}{ Glyphosate rate $\left(\mathrm{g} \mathrm{AE} \mathrm{ha}^{-1}\right)$} \\
\hline 0 & 100.00 & 100.00 & 100.00 \\
\hline 1.8 & 105.62 & 99.28 & 102.91 \\
\hline 3.6 & 93.99 & 102.06 & 97.43 \\
\hline 7.2 & 86.02 & 122.79 & 101.71 \\
\hline 18 & 111.67 & 122.40 & 116.25 \\
\hline 36 & 98.43 & 113.86 & 105.01 \\
\hline 72 & 68.98 & 66.95 & 68.11 \\
\hline 180 & 21.07 & 5.00 & 14.21 \\
\hline 360 & 0.00 & 1.39 & 0.59 \\
\hline 720 & 0.00 & 0.00 & 0.00 \\
\hline $\begin{array}{l}\text { Coefficient of } \\
\quad \text { variation (\%) }\end{array}$ & 32.26 & 17.81 & 21.94 \\
\hline \multicolumn{4}{|l|}{$F$ values: } \\
\hline $\begin{array}{l}\text { Treatments or } \\
\text { doses }\end{array}$ & $20.11^{* *}$ & $78.02^{* *}$ & $46.13^{* *}$ \\
\hline $\begin{array}{l}\text { Hypothesis } \\
f \neq 0\end{array}$ & $0.73^{\text {ns }}$ & $12.05^{* *}$ & $4.39 *$ \\
\hline Regression & $164.11^{* *}$ & $454.57^{* *}$ & $290.50 * *$ \\
\hline Model & Equation (2b) & Equation (1b) & Equation (1b) \\
\hline$R^{2}$ & 0.9738 & 0.9912 & 0.9964 \\
\hline Constants & $\begin{array}{c}g=-4.6485 \\
b=2.6486 \\
k=101.23 \\
D=-1.2178\end{array}$ & $\begin{array}{c}g=-3.9254 \\
b=2.6038 \\
k=104.15 \\
d=-4.3554 \\
f=1.8373\end{array}$ & $\begin{array}{c}g=-4.1192 \\
b=2.5605 \\
k=101.05 \\
d=-2.9156 \\
f=1.0288\end{array}$ \\
\hline
\end{tabular}

ns $=$ not significant $;{ }^{*} P<0.05 ; * * P<0.01$

The determination coefficients and significance levels and constants for the models best fitted to the data obtained for C. benghalensis, E. grandis and P. caribea and the maximum growth predicted by the models and the glyphosate concentrations at which these maximum values took place are provided in Table 5. All models were highly significant and fitted well to the data, as observed from the high $R^{2}$ (0.94-0.99). Except for stem dry weights of $P$. caribea, the model expressed in equation (1b) was used to show stimuli at low doses and inhibition at higher doses. 
Table 4. Mean values of shikimic acid concentrations in soybean and maize shoots harvested 21 days after glyphosate application

\begin{tabular}{|c|c|c|c|}
\hline & \multicolumn{3}{|c|}{$\begin{array}{c}\text { Shikimic acid } \\
\text { concentration ( } \mu \mathrm{gg}^{-1} \\
\text { shoot fresh weight) }\end{array}$} \\
\hline & $\begin{array}{c}\text { Conventional } \\
\text { soybean }\end{array}$ & $\begin{array}{c}\mathrm{RR} \\
\text { soybean }\end{array}$ & Maize \\
\hline \multicolumn{4}{|l|}{ Glyphosate rate $(\mathrm{g} \mathrm{AE} \mathrm{ha-1})$} \\
\hline 0 & $77.07 \mathrm{c}$ & 60.83 & $1.63 \mathrm{~g}$ \\
\hline 1.8 & $361.93 a b$ & 57.50 & $5.02 \mathrm{~g}$ \\
\hline 3.6 & $321.26 b$ & 64.63 & $15.08 \mathrm{fg}$ \\
\hline 7.2 & $310.11 b$ & 62.56 & $27.05 f$ \\
\hline 18 & $311.76 b$ & 57.92 & $51.36 e$ \\
\hline 36 & $338.37 a b$ & 61.41 & $57.33 e$ \\
\hline 72 & $301.00 b$ & 63.89 & $73.66 d$ \\
\hline 180 & $303.36 b$ & 68.26 & $286.96 \mathrm{c}$ \\
\hline 360 & $397.99 a$ & 60.61 & $310.99 b$ \\
\hline 720 & $393.87 a$ & 61.29 & $347.68 \mathrm{a}$ \\
\hline Coefficient of variation (\%) & 15.35 & 19.08 & 10.43 \\
\hline \multicolumn{4}{|l|}{ F-values: } \\
\hline Treatments or doses & $17.67^{* *}$ & $0.36^{\mathrm{ns}}$ & $641.49 * *$ \\
\hline LSD ( $t$-test, $P<0.05)$ & 61.14 & - & 15.68 \\
\hline
\end{tabular}

ns $=$ not significant; $* P<0.01$; means in the same column followed by the same letter do not differ for $P<0.05$.

The same procedure used for conventional soybean and maize was used to select a model for $P$. caribea.

For $C$. benghalensis, the best-fitting models are shown in Fig. 2. Maximum shoot dry weights (195

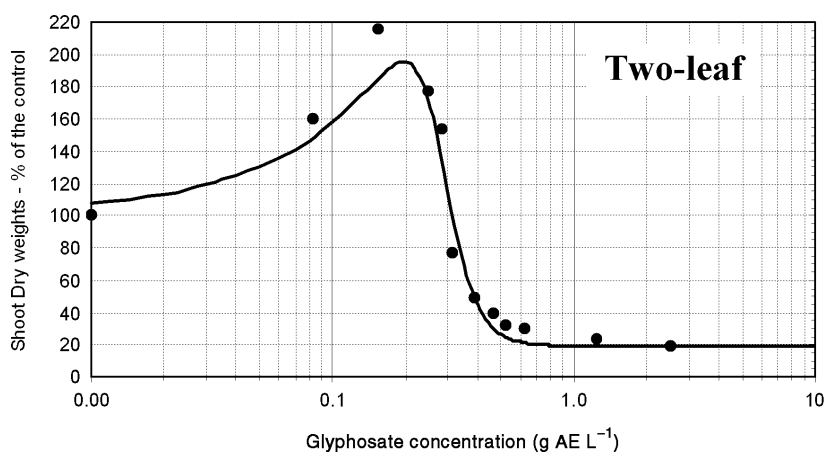

and $142 \%$ of the control) were estimated for 0.02 and $0.098 \%$ concentrations, when glyphosate was applied to plants at the two- or four-leaf stage respectively.

For E. grandis, growth stimuli were observed in all components of the total plant biomass (Figs 3 and 4). Moreover, the maximum stimuli occurred at doses ranging from only 1.9 to $3.7 \mathrm{~g}$ glyphosate $\mathrm{ha}^{-1}$. For roots, the maximum dry weight was more than twice the value in the control. Leaf area was less stimulated than leaf dry weight (maximum values of 140 and $153 \%$ respectively).

For P. caribea, growth stimuli were observed in all components of the total plant biomass except for stem dry weights (Fig. 3). The maximum stimuli occurred at doses from 2.0 to $14.6 \mathrm{~g}$ glyphosate $\mathrm{ha}^{-1}$. According to the models, there was a $52 \%$ increase in the roots brought about by the application of only $2 \mathrm{~g}$ glyphosate $\mathrm{ha}^{-1}$.

\section{DISCUSSION}

Except for glyphosate-resistant, transgenic soybean, low doses of glyphosate stimulated growth of all plant species studied. Stimulation of growth by subtoxic concentrations of a toxin is termed hormesis. ${ }^{8}$ Three previous research papers have reported hormesis with glyphosate, ${ }^{9-11}$ and the authors have mentioned the results shown in Fig. 4 in a short review. ${ }^{8}$ However, a detailed and complete compilation of data on glyphosate-caused hormesis in a variety of species, as provided in this paper, has not been available.

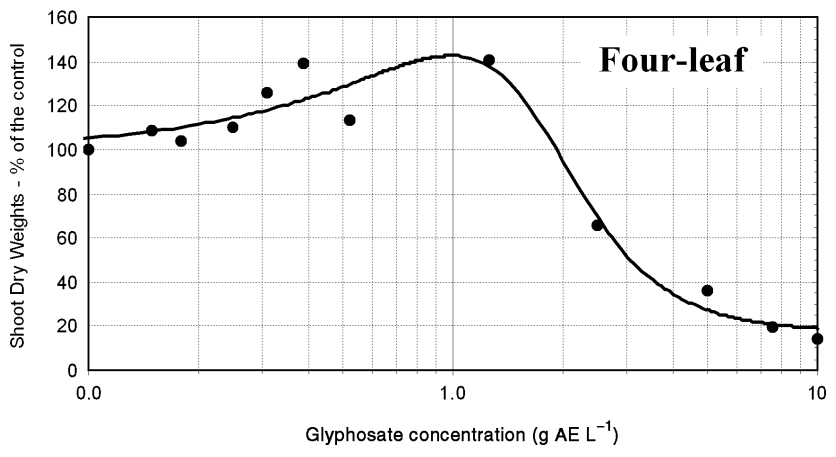

Figure 2. Curves representing Commelina benghalensis dry weights as a result of glyphosate application. Glyphosate was applied at the two-leaf stage (left) and the four-leaf stage (right), 14 or 21 days prior to the harvest respectively.
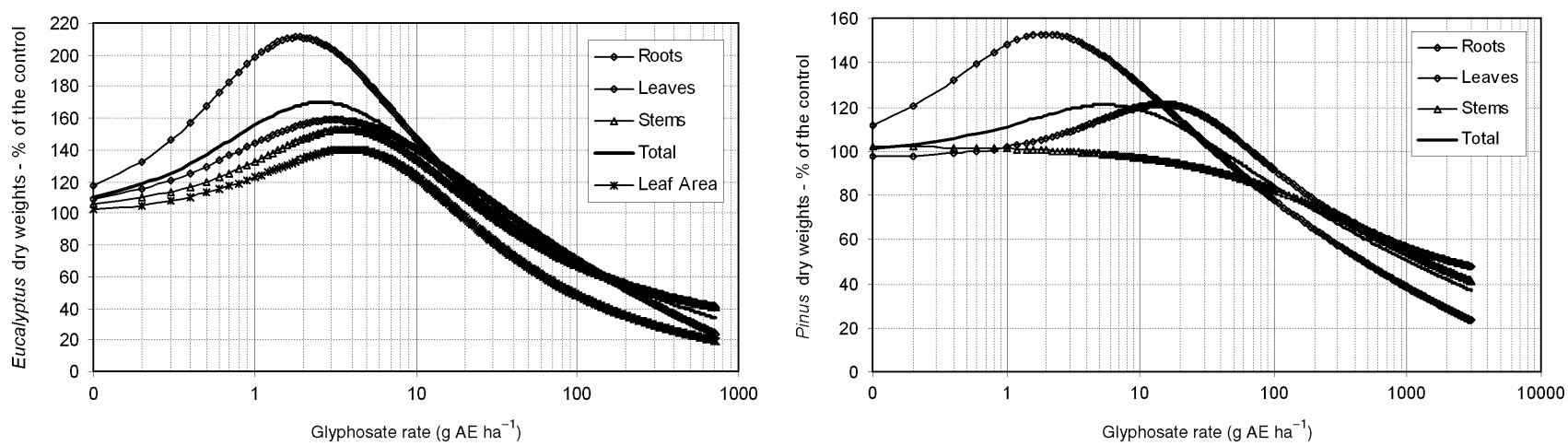

Figure 3. Curves representing Eucalyptus grandis (left) and Pinus caribea (right) dry weights and leaf areas as a result of glyphosate application. Plants were harvested 60 days after glyphosate application. 


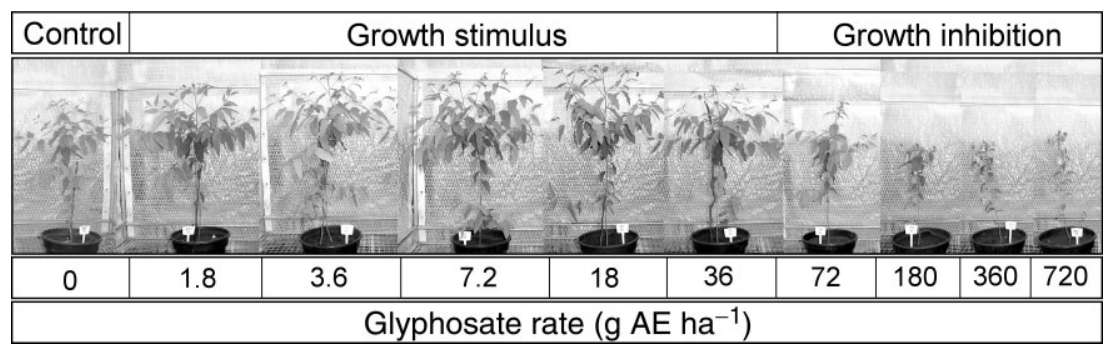

Figure 4. Eucalyptus grandis plants 60 days after glyphosate application at different doses.

Table 5. Determination coefficients, significance levels and coefficients for the models best fitting the data obtained for Commelina benghalensis, Eucalyptus grandis and Pinus caribea. Maximum growth values predicted by the models and the glyphosate concentrations or doses at which these maximum values took place

\begin{tabular}{|c|c|c|c|c|c|c|c|c|c|c|}
\hline \multirow[b]{2}{*}{ Species } & \multirow[b]{2}{*}{ Model } & \multirow[b]{2}{*}{$\mathrm{F}$} & \multirow[b]{2}{*}{$R^{2}$} & \multicolumn{5}{|c|}{ Values of model coefficients } & \multicolumn{2}{|c|}{ Maximum value } \\
\hline & & & & $g$ & $b$ & k & $d$ & $f$ & $\begin{array}{l}\% \text { of } \\
\text { control }\end{array}$ & $\begin{array}{c}\text { Concentration } \\
\text { or rate }\end{array}$ \\
\hline \multicolumn{11}{|c|}{ Commelina benghalensis } \\
\hline $\begin{array}{l}\text { Shoot dry weight (first } \\
\text { experiment) }\end{array}$ & Equation (1b) & $83.22^{* *}$ & 0.9481 & 3.575 & 6.771 & 83.36 & 19.29 & 5523.26 & 195.19 & $0.2 \mathrm{gL}^{-1}$ \\
\hline $\begin{array}{l}\text { Shoot dry weight } \\
\text { (second experiment) }\end{array}$ & Equation (1b) & $21.84^{* *}$ & 0.9656 & 1.755 & 3.471 & 81.55 & 17.52 & 620.51 & 142.50 & $0.98 \mathrm{gL}^{-1}$ \\
\hline \multicolumn{11}{|l|}{ Eucalyptus grandis } \\
\hline Root dry weight & Equation (1b) & $128.65^{* *}$ & 0.9653 & -0.452 & 1.455 & 77.49 & 22.73 & 188.94 & 211.03 & $1.9 \mathrm{gAE} \mathrm{ha}^{-1}$ \\
\hline Leaf dry weight & Equation (1b) & $179.36^{* *}$ & 0.9701 & -0.869 & 1.172 & 191.08 & -90.42 & 128.12 & 158.89 & $3.1 \mathrm{gAEha}^{-1}$ \\
\hline Stem dry weight & Equation (1b) & $108.05^{* *}$ & 0.9397 & -1.355 & 1.428 & 80.39 & 21.02 & 47.24 & 152.89 & $3.6 \mathrm{gAE} \mathrm{ha}^{-1}$ \\
\hline Total dry weight & Equation (1b) & $145.18^{* *}$ & 0.9626 & -0.737 & 1.299 & 109.78 & -9.27 & 118.15 & 169.82 & $2.6 \mathrm{gAE} \mathrm{ha}^{-1}$ \\
\hline Leaf areas & Equation (1b) & $93.71^{* *}$ & 0.9537 & -1.654 & 1.442 & 102.39 & -0.25 & 33.45 & 140.41 & $3.7 \mathrm{gAE} \mathrm{ha}^{-1}$ \\
\hline \multicolumn{11}{|l|}{ Pinus caribea } \\
\hline Root dry weight & Equation (1b) & $67.58^{* *}$ & 0.9148 & -0.196 & 1.140 & 166.15 & -66.17 & 219.56 & 152.93 & $2.0 \mathrm{gAEna}^{-1}$ \\
\hline Leaf dry weight & Equation (1b) & $163.69 * *$ & 0.9144 & -2.913 & 1.374 & 66.05 & 30.74 & 6.18 & 121.25 & 14.6 $\mathrm{gAE} \mathrm{ha}^{-1}$ \\
\hline Stem dry weight & Equation (2b) & $1110.22^{* *}$ & 0.9755 & -6.341 & 0.660 & 81.21 & 20.95 & - & - & - \\
\hline Total dry weight & Equation (1b) & $200.76^{* *}$ & 0.9455 & -1.677 & 1.117 & 158.50 & -59.10 & 37.67 & 120.94 & $5.4 \mathrm{gAE} \mathrm{ha}^{-1}$ \\
\hline
\end{tabular}

** $P<0.01$.

The doses at which maximum effects were observed varied considerably for different plants and tissues. In soybean and maize, the root system was not affected by glyphosate at low doses, but the opposite was observed for $E$. grandis and P. caribea. These results could indicate differences between these two groups of species, but it must be considered that $E$. grandis and $P$. caribea were kept growing for 60 days after glyphosate application, whereas all other crops were maintained for only 14-21 days. The results might indicate that the effects on root systems need more time to occur.

Growth stimulation was observed in C. benghalensis plants at low doses equivalent to doses effectively applied to some plants under field conditions owing to nozzle boom vertical and lateral movements and covering by the crop or the mulch. ${ }^{17}$ The irregularity of the doses reaching individual plants under field conditions could be associated with growth stimulation of plants at low doses, reducing the efficiency of glyphosate to control C. benghalensis and other weed species.

In the present study all the experiments were carried out under greenhouse conditions with no rain or dew formation after the application. To produce similar growth-stimulating low doses under field conditions, higher glyphosate doses might be reduced by rain or dew formation after plants are treated. If the results can be reproduced under field conditions, there would be potential for glyphosate utilization at low doses to improve crop growth or to manipulate plant metabolic pathways to reduce accumulation of specific derivatives of the shikimate pathway. In fact, low doses of glyphosate are used to enhance sucrose accumulation in sugarcane. ${ }^{18-23}$ The mechanism of this effect is not understood, and it is unclear as to whether what is reported in this paper is closely related to the effect in sugarcane, since the concentrations used in sugarcane are $40-180 \mathrm{~g} \mathrm{AE}$ $\mathrm{ha}^{-1}$, and the authors found hormesis at lower doses. However, since lignin synthesis is dependent on the shikimic acid pathway, low doses of glyphosate may inhibit lignification sufficiently to allow more carbon to be partitioned into sucrose. Glyphosate reduces lignification in plants infected by plant pathogens. ${ }^{24}$

The finding that shikimate accumulates at growthstimulating doses of glyphosate in soybean and maize (Fig. 1, Table 4) is indicative that the effect is in some way related to inhibition of EPSPS. The absence 
of any growth effect of glyphosate at any dose on glyphosate-resistant soybean with an insensitive EPSPS supports this hypothesis. The lack of shikimic acid accumulation, even at the highest doses in the glyphosate-resistant soybean variety, is consistent with results of Duke et al. ${ }^{25}$ substantiating that there is no inhibition of EPSPS in such transgenic varieties.

The present results with soybean and maize indicate that elevated shikimate is not necessarily a good predictor of glyphosate damage, although it is a very sensitive indicator of glyphosate exposure. In maize, the degree of elevated shikimate levels might be useful in predicting effects of glyphosate on growth.

The hormetic dose range and response amplitude varied between species, but it also varied between different growth stages of the same species ( $C$. benghalensis).

Further research is needed to evaluate the effects of glyphosate low doses in different plant species and to understand the mechanisms involved. Such work is fundamental to improving present knowledge of glyphosate dynamics in production systems and to having precise information about the effects of glyphosate effects on non-target plants. Measuring individual volumes of spray solutions reaching weeds and evaluating the effects of the minimum doses on the growth of different species can be relevant for understanding and counteracting resistance problems observed under field conditions.

In summary, when applied at high doses, glyphosate was inhibitory to non-transgenic soybean, maize, $C$. benghalensis, $E$. grandis and $P$. caribea. When applied at low doses (ranging from 1.8 to $36 \mathrm{~g} \mathrm{AE} \mathrm{ha}^{-1}$ ), growth stimulation was observed in all studied species except for glyphosate-resistant transgenic soybean. The optimum doses to stimulate growth were distinct for each plant species and each tissue evaluated. The strongest growth stimulation was observed for $C$. benghalensis, $E$. grandis and $P$. caribea, with growth increases of approximately $50-100 \%$ in some tissues of each species. Increases in shikimic acid concentrations might be useful in predicting hormesis caused by glyphosate action at low doses in some species.

As reviewed by Cedergreen et al., ${ }^{9}$ there are very few papers suggesting a molecular mechanism of hormesis in plants. Glyphosate is one of the most studied phytotoxins, with an abundance of information and plant genetic material that can be used to probe the mechanism of hormesis. Thus, the authors expect that the mechanism of the phenomenon described in this paper will soon be discovered.

\section{ACKNOWLEDGEMENT}

The authors thank Dr Mauricio Galo, São Paulo State University, for providing the differential equations for the models used in this research.

\section{REFERENCES}

1 Duke SO, Glyphosate, in Herbicides, Chemistry, Degradation and Mode of Action, Vol. 3, ed. by Kearney PC and Kaufman DD. Marcel Dekker, New York, NY, pp. 1-70 (1988).

2 Amrhein N, Deus B, Gehrke P and Steinrücken HC, The site of the inhibition of the shikimate pathway by glyphosate. II. Interference of glyphosate with chorismate formation in vivo and in vitro. Plant Physiol 66:830-834 (1980).

3 Amrhein N, Deus B, Gehrke P, Hollander H, Schab J, Schulz A, et al., Interference of glyphosate with the shikimate pathway. Proc Plant Growth Regul Soc America 8:99-106 (1981).

4 Becerril J, Duke SO and Lydon J, Glyphosate effects on shikimate pathway products in leaves and flowers of velvetleaf. Phytochemistry 28:695-699 (1989).

5 Singh BK and Shaner DL, Rapid determination of glyphosate injury to plants and identifications of glyphosate-resistant plants. Weed Technol 12:527-530 (1998).

6 Harring T, Streibig JC and Husted S, Accumulation of shikimic acid: a technique for screening glyphosate efficacy. $\mathcal{F}$ Agric Food Chem 46:4406-4412 (1998).

7 Fletcher JS, Pfleeger TG and Ratsch HC, Potential environmental risks associated with the new sulfonylurea herbicides. Environ Sci Technol 27:2250-2252 (1993).

8 Duke SO, Cedergreen N, Velini ED and Belz RG, Hormesis: is it an important factor in herbicide use and allelopathy? Outlooks Pest Manag 17:29-33 (2006).

9 Cedergreen N, Streibig JC, Kudsk P, Mathiassen SK and Duke SO, The occurrence of hormesis in plants and algae. Dose-Response 5:150-162 (2007).

10 Schabenberger O, Kells JJ and Penner D, Statistical tests for hormesis and effective dosage in herbicide dose-response. Agron F 91:713-721 (1999).

11 Wagner R, Kogan $M$ and Parada AM, Phytotoxic activity of root absorbed glyphosate in corn seedlings (Zea mays L.). Weed Biol Manag 3:228-232 (2003).

12 Denis $\mathrm{MH}$ and Delrot S, Carrier-mediated uptake of glyphosate in broad bean (Vicia faba) via phosphate transporter. Physiol Plant 87:568-575 (1993).

13 Morin F, Vera V, Nurit F, Tissut M and Marigo G, Glyphosate uptake in Catharanthus roseus cells: role of a phosphate transporter. Pestic Biochem Physiol 58:13-22 (1997).

14 Brain $\mathrm{P}$ and Cousens $\mathrm{R}$, An equation to describe dose responses where there is stimulation of growth at low doses. Weed Res 29:93-96 (1989).

15 Streibig JC, Models for curve-fitting herbicide dose response data. Acta Agriculturae Scandinavica 30:59-64 (1980).

16 Cedergreen N, Ritz C and Streibig JC, Improved empirical models describing hormesis. Environ Toxicol Chem 24:3166-3172 (2005).

17 Souza RT, Velini ED and Palladini LA, Methodological aspects for spray analysis by punctual deposit determination. Planta Daninha 25:195-202 (2007).

18 Su LY, Cruz AD, Moore PH and Maretzki A, The relationship of glyphosate treatment to sugar metabolism in sugarcane: new physiological insights. F Plant Physiol 140:168-173 (1992).

19 Clowes MSJ, Early and late season chemical ripening of sugarcane. Proc South African Sugar Technologists Assoc 52:160-165 (1978).

20 Clowes MSJ, Ripening activity of the glyphosate salts Mon 8000 and Roundup. Proc South African Sugar Technologists Assoc 54:676-693 (1980).

21 Clowes MSJ and Inman-Bamber NG, Effects of moisture regime, amount of nitrogen applied and variety on the ripening response of sugarcane to glyphosates. Proc South African Sugar Technologists Assoc 54:127-133 (1980).

22 McDonald LM, Morgan T and Kingston G, Chemical ripeners: an opportunity for the Australian sugar industry. Proc Australian Soc Sugarcane Technologists 22:290-295 (2000).

23 Dusky JA, Kang MS, Glaz B and Miller JD, Response of eight sugarcane cultivars to glyphosine and glyphosate ripeners. Plant Growth Regul 4:225-235 (1986). 
24 Liu L, Punja ZK and Rahe JE, Altered root exudation and suppression of induced lignification as mechanisms of predisposition by glyphosate of bean root (Phaseolus vulgaris L.) to colonization by Pythium spp. Physiol Mol Plant Pathol 51:111-127 (1997).
25 Duke SO, Rimando AM, Pace PF, Reddy KN and Smeda RJ, Isoflavone, glyphosate, and aminomethylphosphonic acid levels in seeds of glyphosate-treated, glyphosate-resistant soybean. F Agric Food Chem 51:340-344 (2003). 